\title{
Benthic metabolism and degradation of natural particulate organic matter in carbonate and silicate reef sands of the northern Red Sea
}

\author{
Christian Wild ${ }^{1,4,6, *}$, Mohammed Rasheed ${ }^{2}$, Carin Jantzen $^{3}$, Perran Cook ${ }^{1}$, \\ Ulrich Struck ${ }^{4}$, Markus Huettel ${ }^{5}$, Antje Boetius ${ }^{1}$ \\ ${ }^{1}$ Max Planck Institute for Marine Microbiology, Celsiusstraße 1, 28359 Bremen, Germany \\ ${ }^{2}$ Marine Science Station, University of Jordan and Yarmouk University, PO Box 195, Aqaba, Jordan \\ ${ }^{3}$ Zentrum für Marine Tropenökologie, Fahrenheitstraße 6, 28359 Bremen, Germany \\ ${ }^{4}$ GeoBio-Center, Ludwig-Maximilians University, Richard Wagner Straße 10, 80333 Munich, Germany \\ ${ }^{5}$ Department of Oceanography, Florida State University, Tallahassee, Florida 32306-4320, USA \\ ${ }^{6}$ Present address: UNESCO, IOC, Ocean Sciences Section, 1, rue Miollis, 75015 Paris, France
}

\begin{abstract}
The influence of natural particulate organic matter (POM) input on sedimentary oxygen consumption (SOC) in permeable carbonate and silicate sediments close to a coral reef was investigated in front of the Marine Science Station in Aqaba, Jordan (northern Red Sea). We conducted 7 in situ experiments in stirred benthic chambers. Without additional POM input, SOC rates were similar and not significantly different $(\mathrm{p}>0.5)$ in carbonate and silicate sands, with average rates of $20 \pm 4(\mathrm{n}=10)$ and $16 \pm 2(\mathrm{n}=3) \mathrm{mmol} \mathrm{O}_{2} \mathrm{~m}^{-2} \mathrm{~d}^{-1}$, respectively. Gross photosynthesis in the carbonate and silicate sands accounted for 15 to $23 \mathrm{mmol}$ produced $\mathrm{O}_{2} \mathrm{~m}^{-2} \mathrm{~d}^{-1}$, characterising both sands as largely independent of allochthonous carbon input. SOC of unamended carbonate sands showed no significant variation in 5 in situ experiments conducted within a period of $19 \mathrm{~d}$. Addition of 2 energyrich sources of naturally occurring POM (coral mucus and clam eggs) resulted in significantly $(p<0.0001)$ increased SOC rates in the carbonate sands, but not in the silicate sands. Addition of a suspension containing high concentrations of zooxanthellae did not result in higher SOC in the carbonate sands, indicating that zooxanthellae cannot easily be degraded in reef sediments. Our results highlight the short cut between coral mucus production and degradation in the adjacent reef sands. Suspended particles are initially trapped by the cohesive mucus on the coral surface, and ensuing mucus strings sink to the seafloor at a short distance from the mucus-producing coral. Carbonate sands as porous filter systems obviously harbour more active heterotrophic microbial communities than silicate sands, and thus may constitute a major site of organic matter degradation in the reef ecosystem.
\end{abstract}

KEY WORDS: Coral reef $\cdot$ Permeable sediments $\cdot$ Red Sea $\cdot$ Sedimentary metabolism $\cdot$ Organic matter decomposition $\cdot$ Carbonate sands $\cdot$ Coral mucus

\section{INTRODUCTION}

Coral reefs sustain their high gross primary production (GPP) by various effective processes for recycling of organic matter, thus retaining essential nutrients within the reef ecosystem (Muscatine \& Porter 1977, Crossland \& Barnes 1983, Richter et al. 2001, Wild et al. 2004a). The sandy sediments of reef environments have been described as important sites of organic matter degradation (Rasheed et al. 2003b, 2004, Wild et al. $2004 \mathrm{~b}, \mathrm{c})$. These shallow water sands efficiently couple water column and seafloor processes, since tides, currents and waves filter large volumes of water and dissolved substances through the permeable sediments (Rasheed et al. 2003b, 2004, Wild et al. 2004a,b). Likewise, small suspended particles originating from the 
pelagial are easily transported into the porous sands, which thereby function as a highly effective filter for organic matter. High densities of specialised heterotrophic bacteria attached to the sand grains can rapidly degrade the filtered organic matter (Rusch et al. 2003).

Carbonate sands of biogenic origin are the dominant sediments in reef environments, but terrigenous silicate sands also occur at many sites, especially within fringing reefs located close to the mouth of a river. In the northern Red Sea, rare occurrences of large rain events lead to the deposition of land-derived silicate sands landward of many fringing reef sites. Thus, both kinds of sediments often occur directly next to each other and are exposed to identical environmental conditions.

Carbonates and silicates strongly differ in physicochemical characteristics, e.g. surface structure, dissolution kinetics, transparency to light and heat, and buffering capacity (Schroeder \& Purser 1986). These factors may select for different types of microorganisms and may favour different types of metabolic processes. A main factor may be the higher surface area of carbonate grains which, through their porous structure, provides a larger surface area for biofilm formation than silicate grains (Rasheed et al. 2003a). The main objective of this study was to study metabolism and degradation of organic matter in both kinds of sediments.

Natural sources of particulate organic matter in coral reef environments are phyto- and zooplankton, detritus and organic aggregates forming from exudates and colloidal materials. This study investigated the sedimentary decomposition of these 3 sources of particulate organic matter by using zooxanthellae as typical phytoplankton particulate organic matter (POM), eggs of the giant clam Tridacna squamosa as zooplankton POM, and coral mucus as organic aggregates. The latter were included because former work and our recent work in the Australian Great Barrier Reef showed that coral mucus is an important carrier of energy and nutrients in the reef ecosystem (Benson \& Muscatine 1974, Wild et al. 2004a,b, 2005). In this study, we conducted surveys to assess the potential contribution of coral mucus to the cycling of organic matter in Red Sea fringing reef systems. An indicator for the contribution of coral mucus to the POM pool in the reef system is the formation of visible mucus strings on corals, a process that precedes the release of mucus to the water column. The surveys used the attached mucus strings as indicator and permited a comparison with previously published studies on the Great Barrier Reef.

\section{MATERIALS AND METHODS}

Study sites. This study was conducted in the fringing reef near Aqaba, Jordan and Dahab, Egypt, in the northern Gulf of Aqaba. All chamber experiments took place in a marine reserve close to the Marine Science Station (MSS) in Aqaba (latitude 29 27', longitude $\left.34^{\circ} 58^{\prime}\right)$.

The chamber incubations were conducted at 2 neighboring backreef sites in front of the MSS, the first site covered by carbonate sands (water depth $2.4 \mathrm{~m}$ ), and the second by silicate (quartz) sands (water depth $1.8 \mathrm{~m}$ ) with a $\mathrm{CaCO}_{3}$ content of less than $6 \%$ dry mass. Mean grain size of the carbonate and silicate sands were 559 and $229 \mu \mathrm{m}$ with organic carbon contents of 0.36 and $0.24 \%$, respectively (Rasheed et al. 2003a). Permeability of the sediments, measured with a constant head permeameter (Klute \& Dirksen 1986), was $116 \pm 11 \times 10^{-12} \mathrm{~m}^{2}$ for the carbonate sands and $27 \pm 3 \times$ $10^{-12} \mathrm{~m}^{2}$ for the silicate sands (mean $\pm \mathrm{SD}, \mathrm{n}=3$ ). Porosity, calculated in triplicate from weight loss of wet sediment after drying at $60^{\circ} \mathrm{C}$ for $24 \mathrm{~h}$, was $44 \pm 3$ and $35 \pm 2 \mathrm{vol} / \mathrm{vol}$ for carbonate and silicate sands, respectively. The main identified biogenic components in the carbonate sands were coral skeleton fragments and mollusk shells accounting for more than $50 \%$ of the sediment dry mass. The lateral distance between both sites was approximately $200 \mathrm{~m}$, and both sites were located within a radius of $5 \mathrm{~m}$ from the adjacent coral reef.

Role of coral mucus in the northern Red Sea. To assess the significance of coral mucus as a source for POM in the study area, 6 surveys at 3 different locations in the northern Red Sea $(2$ sites near Dahab, Egypt, 1 site near Aqaba, Jordan, with 2 surveys at each location) were conducted to determine the occurrence of mucus strings on the corals. These studies were carried out at comparable water depths (1 to $4 \mathrm{~m}$ ) and weather conditions (sunny sky, ca. 3 Beaufort wind velocity, no waves). For each survey, between 22 and 115 hard coral colonies were randomly chosen and carefully inspected for strings of coral mucus attached to their surface. In total, 325 colonies were inspected by SCUBA divers. During the 2 surveys in Aqaba, these inspections were carried out for each of 11 dominant hard coral genera as well as for the hydrozoan fire corals Millepora spp. In Dahab, parallel to the described surveys, we also quantified the sedimentation behaviour of a number of the observed mucus strings $(n=18)$ by carefully detaching them from the coral with a weak water flow produced by a plastic pipette. The sinking velocity of the strings was estimated by measuring the height of the strings above the seafloor and the duration required by the detached strings to reach the seafloor. The distance between the coral colony producing the mucus strings and the location of final deposition of the mucus strings on the seafloor was determined with a tape measure. 
Collection of natural organic substrates. Coral mucus: We collected 16 polyps of the hard coral genus Fungia spp. (diameter 4 to $29 \mathrm{~cm}$ ) from water depths of 2 to $4 \mathrm{~m}$ from the reef crest in front of the Marine Science Station. Corals were kept in a flow-through aquarium at in situ temperature $\left(24^{\circ} \mathrm{C}\right)$ and salinity (41) for the study period (May to June 2004). Mucus was collected from the corals by exposing them to air. The polyps immediately started producing and releasing large amounts of mucus. Corals were then turned upside down and the dripping mucus was collected in a clean container. The mucus produced during the first $30 \mathrm{~s}$ was discarded, that produced during the following 2 min was collected for subsequent use. The mucus of 5 to 10 polyps was collected during each sampling. Subsequently, the coral mucus was homogenised with a glass tissue grinder and kept at $4^{\circ} \mathrm{C}$ until further use.

Zooxanthellae: A suspension of freshly released zooxanthellae was collected after exposing 6 Fungia spp. polyps to air for $3 \mathrm{~h}$. Upon being covered with water again, the corals immediately started to release large numbers of zooxanthellae. The overlying water containing the zooxanthellae was collected: this suspension was incubated at $4^{\circ} \mathrm{C}$, which killed the zooxanthellae.

Tridacna squamosa eggs: During the study period May to June 2004, giant clams of the genus Tridacna spp. growing on the attached fringing reef periodically released their gametes into the water. Spawning by these clams usually entails an initial release of sperms, followed by a release of eggs after an interval of minutes to hours to prevent self-fertilisation. We took 3 individuals of Tridacna squamosa from the reef (water depth $10 \mathrm{~m}$ ) and exposed them to air for $1 \mathrm{~h}$. After this stress event they were put in one $1000 \mathrm{l}$ container where they started to release their eggs within $2 \mathrm{~h}$. Egg length was 80 to $90 \mu \mathrm{m}$ and egg density in the suspension was approximately 16 eggs $\mathrm{ml}^{-1}$. A 21 subsample of the container water was kept at $4^{\circ} \mathrm{C}$ until use in the chamber experiments.

Measurement of $\mathbf{C}$ and $\mathbf{N}$ in substrate samples. Samples of particulate organic carbon (POC) and nitrogen (PON) were prepared by filtering replicate aliquots ( $\mathrm{n}=3$ to 6 ) of 2.5 to $15.0 \mathrm{ml}$ of the homogenised mucus solutions, $5.0 \mathrm{ml}$ of the Tridacna squamosa egg solution and $50.0 \mathrm{ml}$ of the zooxanthellae solution onto precombusted GF/F filters (Whatman) to obtain as much organic material on the filters as possible without clogging them. The filters were rinsed with $1 \mathrm{ml}$ distilled water to remove salts and dried for $48 \mathrm{~h}$ at $40^{\circ} \mathrm{C}$. Carbon and nitrogen concentrations on the filters were measured using a THERMO NA
2500 elemental analyser with peptone as standard. Standard deviations of replicate standard concentration measurements were $<3 \%$ of the concentration analysed.

Chamber incubations. Fluxes of $\mathrm{O}_{2}$ were investigated in 7 independent in situ experiments with benthic chambers ( $\mathrm{n}=4$ for each experiment) identical to those described in Huettel \& Gust (1992) and Wild et al. (2004b). Cylindrical chambers of transparent acrylic with a height of $30 \mathrm{~cm}$ and an inner diameter of $19 \mathrm{~cm}$ were used for the incubations. A plastic lid containing a sampling port with syringe holder for water samples and another port to replace the sampled water covered each chamber. The water was circulated by an horizontally rotating disk of $17 \mathrm{~cm}$ diameter. The disk, driven by a $12 \mathrm{~V}$ DC motor, rotated about $8 \mathrm{~cm}$ above the sediment at a computer-controlled speed of $20 \mathrm{rpm}$.

The total duration of each of the chamber experiments was between 330 and $495 \mathrm{~min}$. At the start of each experiment, chambers were inserted gently into the sediment to a depth of about $12 \mathrm{~cm}$, thus including a water column of approximately $20 \mathrm{~cm}$ height, corresponding to a water volume of $5.7 \mathrm{l}$. Special care was taken to remove any air bubbles enclosed in the chambers. All chambers, except those used to measure gross photosynthesis, were shielded from light by wrapping them with opaque PVC foil. At the end of the experiment, the volume of water in the chambers was determined by measuring the exact chamber water height with a ruler. The sediment enclosed in each chamber was checked for large (>1 cm diameter or length) macrofauna organisms (echinoderms, polychaetes and mollusks) by sifting it manually down to a depth of $5 \mathrm{~cm}$. This revealed that in none of the chambers large macrofauna organisms were present.

Addition of organic matter to chambers: An overview of the chamber experiments and the types of organic matter added to the different chambers is given in Table 1 . The 3 organic substrates were injected as suspensions with a known content of

Table 1. Overview of all chamber experiments conducted an hard coral colonies in Aqaba during the field campaign in 2004. DC: dark control; LC: light control; LMA: low mucus addition (40 ml); HMA: high mucus addition $(300 \mathrm{ml})$; EA: egg addition $(200 \mathrm{ml})$; ZA: zooxanthellae addition $(300 \mathrm{ml})$; n: no. of replicates

\begin{tabular}{|lcllc|}
\hline Date (2004) & Expt & Site & Chamber treatment & $\mathrm{n}$ \\
\hline 27 May & A & Carbonate sands & DC & 4 \\
31 May & B & Carbonate sands & DC, LMA & 2,2 \\
4 Jun & C & Carbonate sands & DC, HMA, EA, ZA & $1,1,1,1$ \\
5 Jun & D & Carbonate sands & DC, HMA, EA, ZA & $1,1,1,1$ \\
7 Jun & E & Silicate sands & DC, HMA, EA & $1,2,1$ \\
9 Jun & F & Silicate sands & DC,LC & 2,2 \\
14 Jun & G & Carbonate sands & DC,LC & 2,2 \\
\hline
\end{tabular}


POC and PON (see foregoing subsection) through the sampling port at the beginning of each chamber experiment. Natural POM concentrations in reef water samples were $130 \pm 9 \mu \mathrm{g} \mathrm{POC} \mathrm{l}^{-1}$ and $17 \pm 1 \mu \mathrm{g} \mathrm{PON} \mathrm{l}^{-1}$ (mean $\pm \mathrm{SD}, \mathrm{n}=6$ ). Coral mucus was added to the chambers in quantities of 60 (Expt B) to 400 (Expts C,

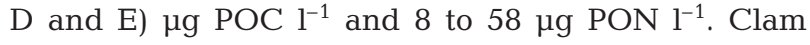
eggs were added to the chambers in average quantities of $1500 \mu \mathrm{g}$ POC $\mathrm{l}^{-1}$ and $150 \mu \mathrm{g}$ PON $\mathrm{l}^{-1}$. Zooxanthellae were added to the chambers in quantities of $95 \mu \mathrm{g}$ POC $\mathrm{l}^{-1}$ and $11 \mu \mathrm{g} \mathrm{PON}^{-1}$. The turnover of $\mathrm{C}$ in each experiment was calculated by using the POC measurements and the increase in SOC in each chamber with substrate addition relative to the controls, assuming that $1 \mathrm{~mol}$ added $\mathrm{C}$ is oxidised by $1 \mathrm{~mol} \mathrm{O}_{2}$.

Sample collection and subsequent analyses: Water samples (60 to $100 \mathrm{ml}$ ) were taken at pre-set time intervals (30 to $120 \mathrm{~min}$ ) from the chamber water for later analyses of $\mathrm{O}_{2}$ concentrations. Fixed samples were measured within $1 \mathrm{~h}$ by the Winkler titration method
(Winkler 1888). Fluxes of $\mathrm{O}_{2}$ were evaluated by linear regression of solute concentration over time (at least 4 data points).

\section{RESULTS}

\section{Role of coral mucus in the northern Red Sea}

A total of 325 hard coral colonies were inspected during 6 surveys in the northern Red Sea. Strings of coral mucus could be detected on roughly half of them (Table 2). In each survey, between 42 and $65 \%$ of all corals had mucus strings attached to their surfaces, often located laterally or underneath the coral surface (Fig. 1). The hydrozoan fire corals genus Millepora spp. had the highest incidence of mucus strings (72\% of all inspected corals), and in most cases more than 1 string could be detected on their surfaces. More than half of all inspected hard corals of the genera Stylophora and Fungia had mucus strings attached to their
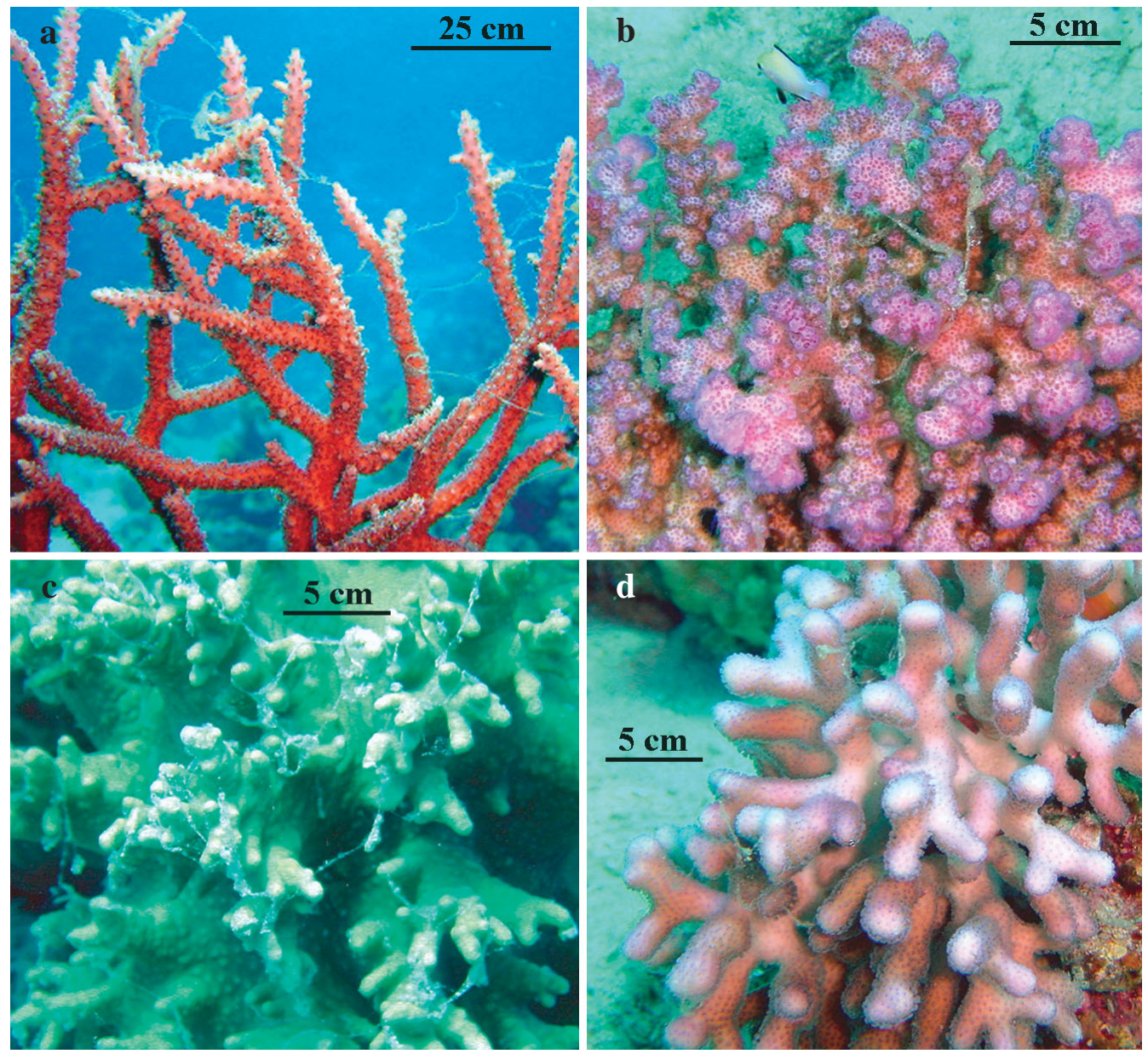

Fig. 1. Strings of mucus observed on different corals in the northern Red Sea. (a) Acropora spp., (b) Pocillopora spp., (c) soft coral Lobophyton spp., (d) Stylophora spp. 
Table 2. Coral mucus strings observed on various hard coral colonies during 6 surveys in the northern Red Sea. MSS: Marine Science Station

\begin{tabular}{|c|c|c|c|c|}
\hline $\begin{array}{l}\text { Date } \\
(2004)\end{array}$ & Location & $\begin{array}{l}\text { No. of co } \\
\text { Inspected }\end{array}$ & $\begin{array}{l}\text { ral colonies } \\
\text { With mucus } \\
\text { strings }\end{array}$ & $(\%)$ \\
\hline 12 May & Dahab, Three Pools & 22 & 12 & 55 \\
\hline 12 May & Dahab, Three Pools & 27 & 12 & 44 \\
\hline 18 May & Dahab, Lagoon & 23 & 15 & 65 \\
\hline 18 May & Dahab, Lagoon & 49 & 21 & 43 \\
\hline 1 Jun & Aqaba, MSS reef & 89 & 37 & 42 \\
\hline 1 Jun & Aqaba, MSS reef & 115 & 57 & 50 \\
\hline Total & & 325 & 154 & 47 \\
\hline
\end{tabular}

surfaces. No strings could be detected on the massive corals Galaxea spp. and Favia spp. (data not shown).

Microscopic observation of a number of freshly collected mucus strings showed an intense contamination with phyto- and zooplankton organisms as well as unidentifiable detritus and small carbonate grains (Fig. 2). Consequently, all 18 tested mucus strings showed negative buoyancy and started to sink if de- tached from the coral. Resulting sedimentation velocities were between 0.3 and $2.5 \mathrm{~cm} \mathrm{~s}^{-1}$. The place of sedimentation on the seafloor was located within a distance of 0 to $125 \mathrm{~cm}$ relative to the place at which the string had been attached to the producing colony.

\section{Chamber experiments}

Sedimentary $\mathrm{O}_{2}$ consumption and gross photosynthesis

The $\mathrm{O}_{2}$ concentration decreased in all 4 chambers during Chamber Expt A. The resulting sedimentary $\mathrm{O}_{2}$ consumption rates ranged from 13 to $25 \mathrm{mmol} \mathrm{m} \mathrm{m}^{-2}$ $\left(20 \pm 5 \mathrm{mmol} \mathrm{O} \mathrm{m}^{-2} \mathrm{~d}^{-1}\right.$, mean $\left.\pm \mathrm{SD}\right)$. The addition of small coral mucus volumes $(40 \mathrm{ml}$, equivalent to an input of $30.1 \mu \mathrm{mol} C$ and $3.5 \mu \mathrm{mol} \mathrm{N}$ ) during Chamber Expt $\mathrm{B}$ did not produce a detectable increase in $\mathrm{O}_{2}$ consumption compared to the control chambers. Sedimentary $\mathrm{O}_{2}$ consumption was $22 \pm 6 \mathrm{mmol} \mathrm{m}^{-2} \mathrm{~d}^{-1}(\mathrm{n}=4)$, and thus not significantly different (2-tailed $t$-test, $\mathrm{p}>$ 0.05) from the 4 untreated dark chambers of Expt A used as control.

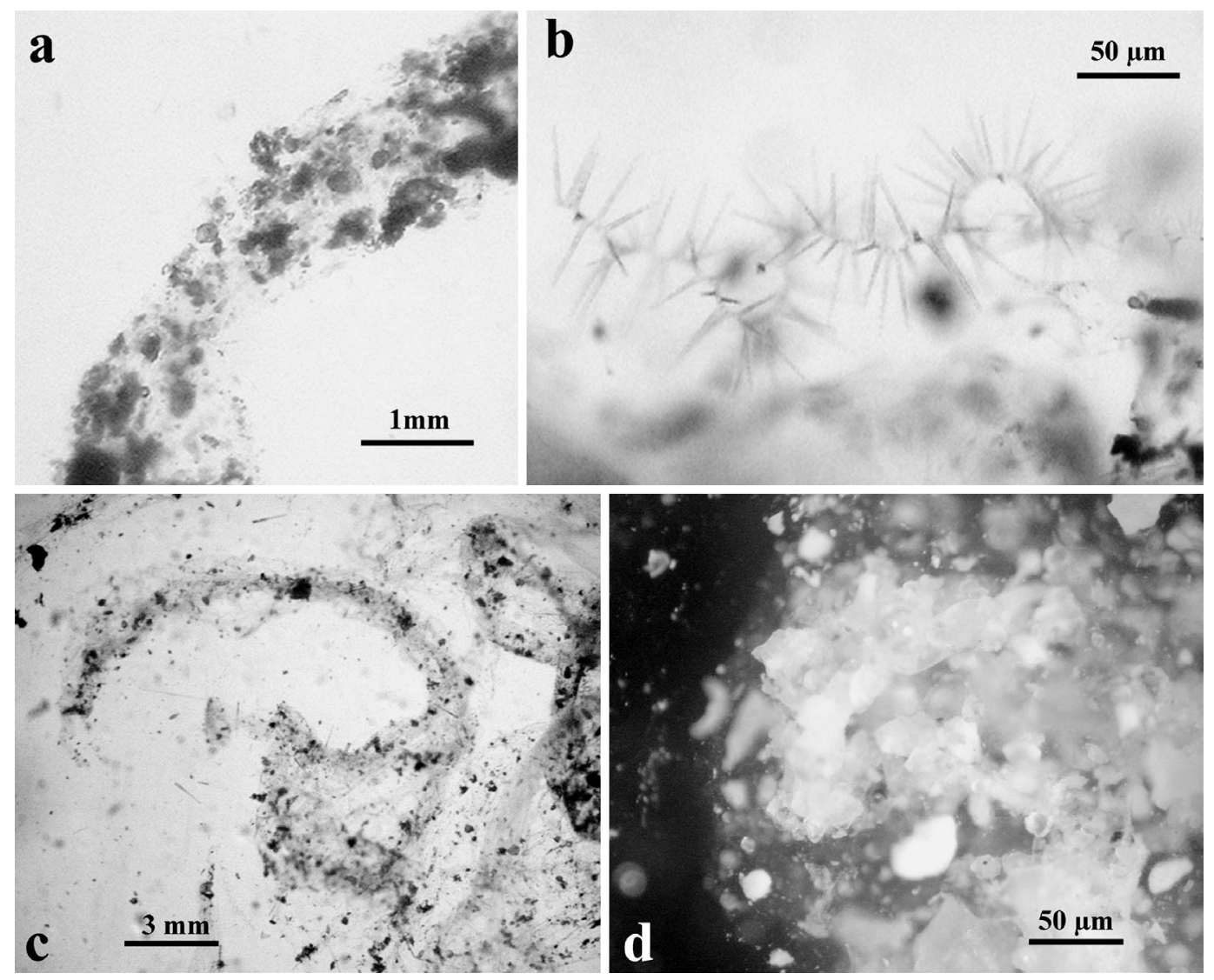

Fig. 2. Acropora spp. Microscopic observation of mucus strings freshly collected from several colonies. (a) Heavy contamination of the initially transparent mucus. Among several other unidentifiable contaminants, (b) diatom chains, (c) diatom frustules, and (d) carbonate grains were observed on the mucus strings 

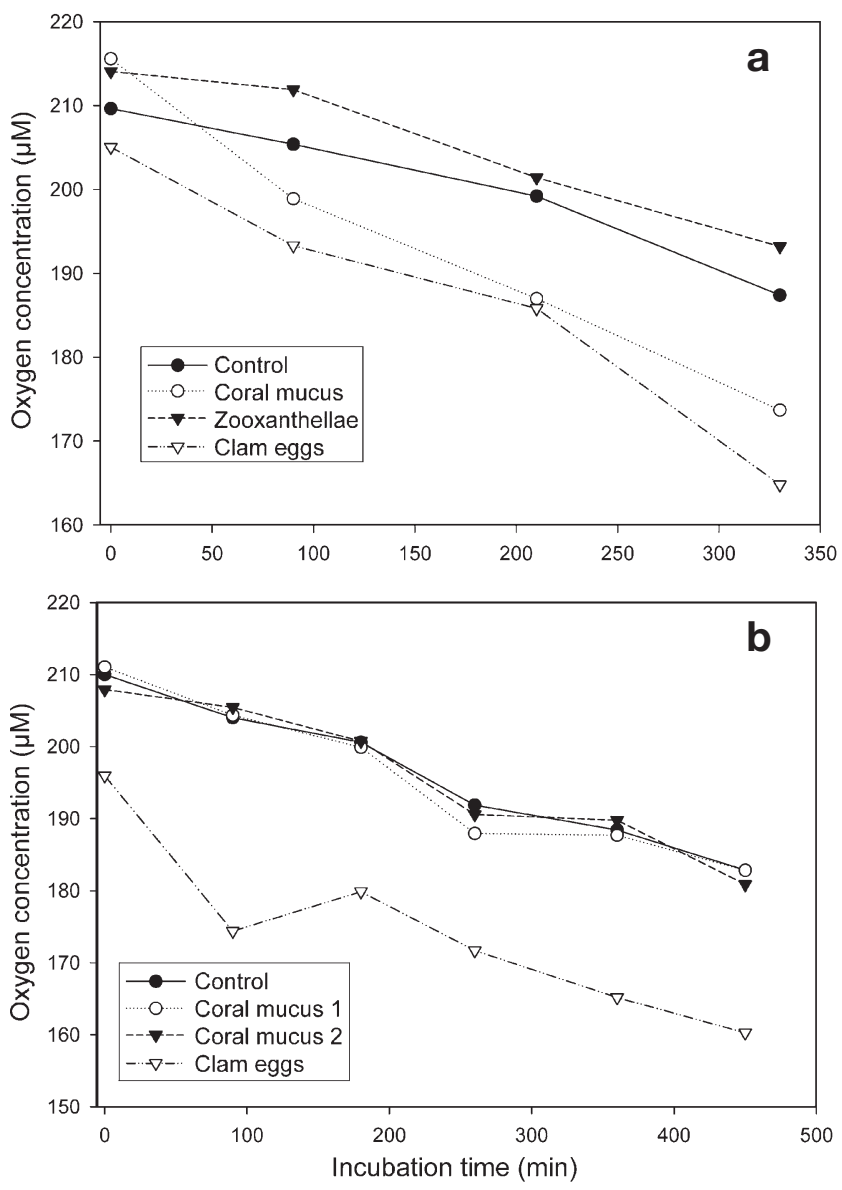

Fig. 3. (a) In situ Chamber Expt C, and (b) in situ Chamber Expt E showing $\mathrm{O}_{2}$ concentration in 4 light protected benthic chambers that were simultaneously deployed on (a) carbonate sands and (b) silicate sand, to measure sedimentary degradation of different sources of added particulate organic matter

Fig. 3a shows that decreases in $\mathrm{O}_{2}$ concentration in the control chamber and in the chamber with zooxanthellae addition in Expt $\mathrm{C}$ on carbonate sands were very similar, with SOC rates of 18.9 and $19.2 \mathrm{mmol} \mathrm{m}^{-2} \mathrm{~d}^{-1}$, respectively. However, $\mathrm{O}_{2}$ consumption was significantly higher (2-tailed $t$-test, $\mathrm{p}<0.0001$ ) in the chamber with the addition of large coral mucus volumes $(300 \mathrm{ml}$; $230 \mu \mathrm{mol} \mathrm{C}$ and $28 \mu \mathrm{mol} \mathrm{N}$ ) and clam eggs (200 ml; $900 \mu \mathrm{mol} \mathrm{C}$ and $72 \mu \mathrm{mol} \mathrm{N}$ ) (Fig. 3a), with corresponding SOC rates of 37 and $33 \mathrm{mmol}$ $\mathrm{m}^{-2} \mathrm{~d}^{-1}$, respectively (Table 3 ). The results of the replicate experiment $\mathrm{D}$ with an identical experimental design and substrate addition confirm the findings of Expt $\mathrm{C}$ (data not shown in figure). Hence, $\mathrm{O}_{2}$ consumption in the chambers with mucus and egg addition were 33 and $34 \mathrm{mmol} \mathrm{m}^{-2} \mathrm{~d}^{-1}$, respectively, compared to 22 and $13 \mathrm{mmol} \mathrm{m}^{-2} \mathrm{~d}^{-1}$ in the control chamber and the chamber with addition of zooxanthellae, respectively.
In contrast, the addition of coral mucus and coral eggs to chambers deployed on silicate sands in Expt E resulted in only minor differences in $\mathrm{O}_{2}$ concentration decrease compared to the control chamber (Fig. 3b). Absolute $\mathrm{O}_{2}$ concentration was lower in the chamber with added clam eggs, but the concentration decrease was very similar to that in the other 3 chambers. The resulting SOC rates were very similar and ranged between 17 and $20 \mathrm{mmol} \mathrm{O}_{2} \mathrm{~m}^{-2} \mathrm{~d}^{-1}$ (Table 3).

Expts G (carbonate sands) and F (silicate sands) were carried out to compare gross photosynthesis rates in the light to oxygen consumption in the dark (Fig. 4). The resulting mean rates of gross photosynthesis were $19 \pm 6 \mathrm{mmol} \mathrm{O}_{2} \mathrm{~m}^{-2} \mathrm{~d}^{-1}$ for the carbonate sands and $15 \pm 0.2 \mathrm{mmol} \mathrm{O}_{2} \mathrm{~m}^{-2} \mathrm{~d}^{-1}$ for the silicate sands. Mean sedimentary oxygen consumption was $20 \pm 3$ and $15 \pm$ $1 \mathrm{mmol} \mathrm{O}_{2} \mathrm{~m}^{-2} \mathrm{~d}^{-1}$ for the carbonate and silicate sands, respectively (ranges of all gross photosynthesis SOC and GP rates are shown in Table 3). Photosynthetic $\mathrm{O}_{2}$ production equalled SOC in both sediments over the experimental period. SOC in carbonate sands showed no significant variation during the study period of $4 \mathrm{wk}$ in May and June.

\section{Carbon turnover}

Table 4 presents an overview of the calculated carbon turnover in all chambers with substrate addition, except for the 2 mucus chambers with low mucus addition from Expt B, which did not show any increased SOC rate compared to the control chambers. The highest $\mathrm{C}$ turnover was observed in the 2 mucus chambers deployed on carbonate sands during Expts C and D. Between 5 and $9 \%$ of the added $C$ as coral mucus was respired $\mathrm{h}^{-1}$, highlighting the high degradability of this substrate for heterotrophic bacteria in carbonate sands. In contrast, the same substrate quantity and quality was degraded in the silicate sands at very low rates of $<0.3 \% \mathrm{C}$ turnover $\mathrm{h}^{-1}$. Clam eggs were degraded in the carbonate sands at $\mathrm{C}$ turnover rates that were more than 2 times lower than those of coral mucus, whereas they were degraded in the silicate

Table 3. Values of sedimentary oxygen consumption (SOC) and gross photosynthesis rates (mmol $\mathrm{O}_{2}$ consumed or released $\mathrm{m}^{-2} \mathrm{~d}^{-1}$ ) measured in all chamber experiments. nd: no data

\begin{tabular}{|lcc|}
\hline Parameter & Carbonate sands & Silicate sands \\
\hline SOC control & $13-25(\mathrm{n}=10)$ & $14-20(\mathrm{n}=3)$ \\
Gross photosynthesis & $15,23(\mathrm{n}=2)$ & $15,16(\mathrm{n}=2)$ \\
SOC with addition of coral mucus & $33,37(\mathrm{n}=2)$ & $17,18(\mathrm{n}=2)$ \\
SOC with addition of clam eggs & $33,34(\mathrm{n}=2)$ & $20(\mathrm{n}=1)$ \\
SOC with addition of zooxanthellae & $13,19(\mathrm{n}=2)$ & $\mathrm{nd}$ \\
\hline
\end{tabular}


sands at very low $\mathrm{C}$ turnover rates of $0.3 \% \mathrm{~h}^{-1}$ (Table 4 ). Zooxanthellae, added to the chambers with carbonate sands, were barely degraded. Only 1 of 2 experimental chambers showed a low $\mathrm{C}$ turnover of $0.7 \% \mathrm{~h}^{-1}$.
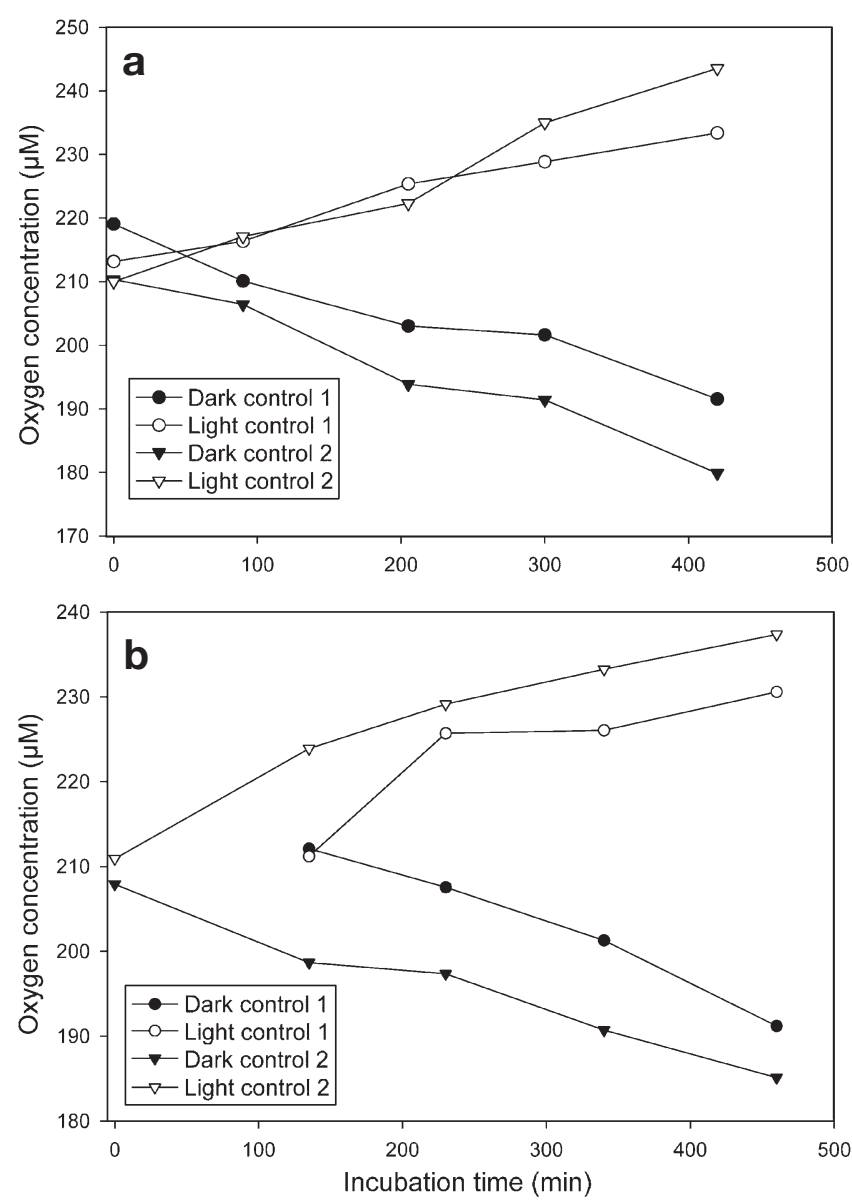

Fig. 4. (a) In situ Chamber Expt G and (b) in situ Expt F, showing $\mathrm{O}_{2}$ concentration in 4 benthic chambers (2 light-protected, 2 transparent) simultaneously deployed on (a) carbonate sands and (b) silicate sands to compare gross photosynthesis and sedimentary $\mathrm{O}_{2}$ consumption

\section{DISCUSSION}

\section{Coral mucus release in the northern Red Sea}

The surveys revealed that corals mucus strings occur on many different genera of hard and hydrozoan fire corals of the study area in the northern Red Sea. We also observed these strings on several soft corals. Because of a lack of strong tidal currents, mucus stays longer on the coral surface in this area than (for instance) in the Heron Island reef system of the Great Barrier Reef that we investigated in previous studies (Wild et al. 2004a,b). Thus, trapping of numerous particles by the adhesive mucus matrix already occurred while it was still attached to the coral. This mechanism is different from the trapping of particles by drifting coral mucus aggregates in a reef system with enclosed lagoon and strong tidal currents as described by Wild et al. (2004a). However, our results confirm the suggestion of Pascal \& Vacelet (1981) that coral mucus from the reefs of Aqaba seems to be a major trap for suspended detritus and phytoplankton.

The composition of particulate material attached to the mucus strings (larger phyto- and zooplankton detritus, many carbonate grains) was very similar to that of POM trapped by the mucus floats described by Wild et al. (2004a). These mucus floats are the last stage in the ageing process of coral mucus aggregates during their drift through the lagoon water column, and display a sedimentation behaviour with sinking rates of 4 to $8 \mathrm{~cm}$ $\mathrm{s}^{-1}$, which is a somewhat higher rate than those measured in the present study ( 0.3 to $2.5 \mathrm{~cm} \mathrm{~s}^{-1}$ ).

In the prevailing slow water currents of the Red Sea reefs, detached mucus aggregates sink to the reef sands very close $(<2 \mathrm{~m})$ to the producing colony. Our chamber experiments revealed that coral mucus can be degraded rapidly in the adjacent carbonate reef sands. This may lead to a release of nutrients with direct benefit to the corals. The cycling of elements via coral mucus in the Red Sea consequently may even be

Table 4. Turnover of $\mathrm{C}$ added as natural organic substrates during the different chamber experiments. Vol. substr. add.: volume of substrate added; $\mathrm{C}$ substr. cont.: $\mathrm{C}$ substrate content; $\mathrm{O}_{2}$ cons. - Contr.: consumption minus that in relative control chamber

\begin{tabular}{|c|c|c|c|c|c|c|}
\hline Sediment & Substrate & $\begin{array}{l}\text { Vol. substr. add. } \\
\qquad(\mathrm{ml})\end{array}$ & $\begin{array}{l}\text { C substr. cont. } \\
\left(\mathrm{mg} \mathrm{l}^{-1}\right)\end{array}$ & $\begin{array}{l}\text { C added } \\
(\mu \mathrm{mol})\end{array}$ & $\begin{array}{c}\mathrm{O}_{2} \text { cons. }- \text { Contr. } \\
\left(\mu \mathrm{mol} \text { chamber }{ }^{-1} \mathrm{~h}^{-1}\right)\end{array}$ & $\begin{array}{c}\text { C turnover } \\
\left(\% \mathrm{~h}^{-1}\right)\end{array}$ \\
\hline Carbonate & Clam eggs & 200 & 54 & 897 & 12.9 & 1.4 \\
\hline Carbonate & Clam eggs & 200 & 54 & 897 & 17.1 & 1.9 \\
\hline Carbonate & Coral mucus & 300 & 9 & 231 & 11.1 & 4.8 \\
\hline Carbonate & Coral mucus & 300 & 9 & 231 & 20.4 & 8.8 \\
\hline Carbonate & Zooxanthellae & 300 & 2 & 54 & 0.0 & 0.0 \\
\hline Carbonate & Zooxanthellae & 300 & 2 & 54 & 0.4 & 0.7 \\
\hline Silicate & Clam eggs & 200 & 54 & 897 & 2.5 & 0.3 \\
\hline Silicate & Coral mucus & 300 & 9 & 231 & 0.6 & 0.3 \\
\hline Silicate & Coral mucus & 300 & 9 & 231 & 0.1 & 0.04 \\
\hline
\end{tabular}


shorter than that described by Wild et al. (2004a) for Heron Island, Australia. Through this mechanism, essential nutrients can be retained and recycled within the reef ecosystem. Thus, coral mucus also seems to have an important function in the recycling of nutrients in Red Sea fringing reefs with open lagoons.

\section{Metabolism of carbonate and silicate sands}

Both investigated sediments, carbonate and silicate sands, come from the same ecosystem and receive the same amount of organic matter supply. Photosynthetic $\mathrm{O}_{2}$ production and SOC in both sediments were similar: approximately $20 \mathrm{mmol} \mathrm{O}_{2} \mathrm{~m}^{-2} \mathrm{~d}^{-1}$ during our experiments. In the laboratory, Rasheed et al. (2003a) found lower rates of 5 to $6 \mathrm{mmol} \mathrm{m}^{-2} \mathrm{~d}^{-1}$ for carbonate and silicate sands from the same study site, but their results confirm the SOC similarity in both sediment types. The quantitative difference may be attributable to laboratory artifacts such as sieving of the sediment, but not to different incubation temperatures (24 to $25^{\circ} \mathrm{C}$ in both studies). SOC measured in situ with identical chamber experiments in carbonate sands of Heron Island, Australia, were approximately $50 \mathrm{mmol}$ $\mathrm{m}^{-2} \mathrm{~d}^{-1}$ (Wild et al. 2004a,b). This higher rates may be attributable to a larger grain size (829 vs. $559 \mu \mathrm{m})$ and hence higher permeability and filtration rates, as well as higher water temperatures $\left(28\right.$ vs. $\left.24^{\circ} \mathrm{C}\right)$ at Heron Island than at Aqaba. Clavero et al. (2000) demonstrated that fluxes of solutes increase with increasing temperatures, facilitating biological activity. SOC rates at Aqaba were also similar to those measured at a variety of different field sites, e.g. 13 to $38 \mathrm{mmol} \mathrm{m}^{-2}$ $\mathrm{d}^{-1}$ in Hiroshima Bay (Seiki et al. 1989, 1994) and $35 \mathrm{mmol} \mathrm{m}^{-2} \mathrm{~d}^{-1}$ in a coastal lagoon in the South Atlantic Bight (Marinelli et al. 1998).

The similarity of gross photosynthesis and SOC characterises both sands as largely independent of allochthonous carbon input. Net photosynthesis was only $0.8 \mathrm{mmol} \mathrm{m}^{-2} \mathrm{~d}^{-1}$ in the silicate sands, whereas in the carbonate sands photosynthetic $\mathrm{O}_{2}$ production did not compensate for respiration in the dark (net photosynthesis was $-0.9 \mathrm{mmol} \mathrm{m}^{-2} \mathrm{~d}^{-1}$ ). Green mats of filamentous algae covering ca. $30 \%$ of the silicate sediment surface during May and June 2004 suggest the possible net-autotrophic character of these sands, whereas carbonate sands in the Red Sea may be more net-heterotrophic because of their higher organic matter degradation rate at the same photosynthesis rates. The comparative pigment profiles of carbonate and silicate sands measured in March 2002 (Rasheed et al. 2003a) and September 2004 (Rasheed \& Wild unpubl. data) showed no higher chlorophyll a concentrations in the surface layer ( 0 to $10 \mathrm{~cm}$ sediment depth) of silicate sands. At Heron Island, Australia, it was found that gross photosynthesis of carbonate reef sands was $163 \mathrm{mmol} \mathrm{O}_{2} \mathrm{~m}^{-2} \mathrm{~d}^{-1}$, much higher than the SOC rates in the same sediments of $65 \mathrm{mmol} \mathrm{O}_{2} \mathrm{~m}^{-2} \mathrm{~d}^{-1}$ (Rasheed et al. 2004).

\section{Organic matter degradation in carbonate and silicate sands}

Carbonate sands showed a fast reaction to the addition of energy-rich POM (mucus + eggs), while silicate sands did not show this response. The 2-fold larger grain size of the carbonate compared to the silicate sands may affect the permeability and porosity of the respective sediments. Rasheed et al. (2003a) found a stronger reaction to the addition of the cyanobacterium Spirulina sp. in carbonate sands than in silicate sands, and attributed this difference to the higher permeability of carbonate sands leading to a more intense transport of organic matter into the sands via advection. This is confirmed by the measurements in this study and in other studies of Rasheed et al. (2003a,b), who found a 4 - to 8 -fold higher permeability and fluid exchange in carbonate sands than in silicate sands from the same study site. In addition, the porous surface structure of carbonate sands may be more effective in retaining POM than the relatively smooth surfaces of silicate sands. It was found that carbonate sands may exhibit a 50\% larger specific surface area (Rasheed et al. 2003a) and 30\% higher porosity (present study) than silicate sands of a similar grain size; this is critical for microbial colonisation. Wild et al. (2004b, and unpubl. data) found high bacteria densities in carbonate sands from Australia, the Red Sea and Hawaii, with cell numbers of $10^{9}$ to $10^{10} \mathrm{~cm}^{-3}$, resulting from the large specific surface area available as settling substrate for microorganisms, and the fact that bacteria exist also within the matrix of carbonate grains. Bacteria abundance is about 1 order of magnitude higher than bacteria counts in silicate sands of the same grain size (Rusch et al. in press) and may partly explain the 50 -fold and 6-fold stronger response of carbonate sands to the addition of coral mucus and clam eggs. It is also possible that different properties (e.g. buffering and heat capacity, transparency) of both sediments caused the differences in organic matter degradation rates. Another reason could be that bacteria communities in carbonate sands differ from those in silicate sands. Specific bacteria living in and on the carbonate grains may be differently adapted to the rapid degradation of organic matter transported into the sandy sediments via advective processes. This aspect needs further study with molecular tools that allow identification of the phylogeny and function of microbial popula- 
tions (Llobet-Brossa et al. 2002). Irrespective of the exact mechanisms, the rapid response of carbonate sediments to organic matter input suggests that much of the organic matter produced within the coral reef ecosystem will also be degraded on site, rather than being exported to adjacent ocean waters. This is in agreement with the observations of Duarte \& Cebrian (1996), who reported that $76 \%$ of primary production by reef algae was degraded within the coral reef ecosystem, the highest value amongst the 8 ecosystem types covered by their study.

Carbon turnover in the chambers with mucus addition was 5 to $8 \% \mathrm{~h}^{-1}$. This is very similar to the rates of $\mathrm{C}$ turnover (at least $7 \% \mathrm{C} \mathrm{h}^{-1}$ ) derived from chamber experiments with coral mucus addition at Heron Island, Australia (Wild et al. 2004b). The addition of zooxanthellae did not cause increased SOC rates, not even in the carbonate sands. This may be due to the quality and reactivity of the added organic matter, which affects microbial remineralization, and depend on its molecular as well as its biochemical composition (Westrich \& Berner 1984, Dauwe et al. 1999). Like other symbiotic dinoflagellates, zooxanthellae possess a stable shell composed of cellulose (Markell et al. 1992), a polysaccharide that can only be degraded by a few specialized microorganisms (Hedges \& Oades 1997, Pareek et al. 2000). In contrast, coral mucus contains a variety of monosaccharides, free amino acids, proteins and lipids (Benson \& Muscatine 1974, Ducklow \& Mitchell 1979, Krupp 1981, Pascal \& Vacelet 1981, Meikle et al. 1988, Wahbeh \& Mahasneh 1989, Wild et al. 2005), characterizing this substrate as an energy and nutrient source for microbes. We can also assume that Tridacna squamosa eggs are mainly composed of proteins and lipids, as found by Sedano et al. (1995) for another bivalve, Mytilus galloprovincialis. A higher C:N ratio (16 to 21) was found for coral eggs (Wild et al. 2004c) than for coral mucus (5 to 14) (Wild et al. 2004a). This and the higher $\mathrm{C}$ turnover of coral mucus (5 to $9 \% \mathrm{C} \mathrm{h}^{-1}$ ) compared to clam eggs (1 to $2 \%$ $\mathrm{C} \mathrm{h}^{-1}$ ) indicate a higher reactivity of coral mucus.

In conclusion, our research demonstrated that permeable carbonate reef sands are sites of efficient organic matter degradation, with decomposition rates exceeding those of silicate sands of similar grain size exposed to the same environmental conditions. The higher specific surface area and associated higher densities of bacterial colonisation may be the leading causes for the higher decomposition rates in the carbonate, but also the higher sediment permeability due to the porosity and surface roughness of the grains may enhance organic matter uptake and degradation in the carbonate sands. Because these carbonate sands cover the reef around the corals, they are the primary recipients of sinking organic material produced and released from living corals, i.e. particle-enriched mucus. Corals invest a large amount of the energy harvested by their symbiotic zooxanthellae in mucus (approximately $50 \%$; Crossland et al. 1980, Davies 1984); thus, recovering some of the nutrients released with the mucus should provide a significant ecological advantage. The rapid decomposition of the mucus and trapped particles in the sediment in close vicinity to the corals permits this efficient recycling, and in a fringing reef may fulfil the same role as the decomposition of mucus in the lagoon sediments of circular reef plateaus or atolls, as reported earlier by Crossland et al. (1980), Davies (1984), and Wild et al. (2004a,b). Our present study expands this coral-permeable sediment-recycling hypothesis to other important particulate organic matter species in the reef environment, namely spawning products and zooxanthellae. Large amounts of spawning products reach the reef sediments after mass spawning events of reef organisms (e.g. Wild et al. 2004c), underlining the importance of permeable reef sands for the recycling of the nutrients contained in these products. Coral bleaching events, which have recently became more frequent (possibly due to temperature increases in the marine environment) (Hoegh-Guldberg 1999), represent mass releases of zooxanthellae to reef waters. Our study has shown that despite a probable substantial filtration of these algae from the water column by the permeable reef sands (Huettel \& Rusch 2000), a rapid degradation of this rich particulate organic matter in the sands may be not possible. Our study suggests that bleaching events may not result in an immediate return of nutrients (as seen for Tridacna squamosa eggs) and, if water currents are present, may instead result in a relatively larger loss of nutrients from the reef system in comparison to rapidly degrading POM as spawning products and coral mucus.

Acknowledgements. We are grateful to H. A. Roa-Quiaoit for providing Tridacna squamosa eggs. B. B. Jørgensen and M. Badran are acknowledged for their support of this work. Many thanks are also due to F. Eder and A. Haas for their help during the surveys, to R. Tollrian and C. Richter for logistical support, and to 3 anonymous referees for improving the manuscript. The Max Planck Society, Germany, funded this research.

\section{LITERATURE CITED}

Benson AA, Muscatine L (1974) Wax in coral mucus: energy transfer from corals from corals to reef fishes. Limnol Oceanogr 19:810-814

Clavero V, Izquierdo JJ, Fernandez JA, Niell FX (2000) Seasonal fluxes of phosphate and ammonium across the sediment-water interface in a shallow small estuary (Palmones River, southern Spain). Mar Ecol Prog Ser 198: $51-60$ 
Crossland CJ, Barnes DJ (1983) Dissolved nutrients and organic particulates in water flowing over coral reefs at Lizard Island. Austr J Mar Freshw Res 34:835-844

Crossland C, Barnes D, Borowitzka M (1980) Diurnal lipid and mucus production in the staghorn coral Acropora acuminata. Mar Biol 60:81-90

Dauwe B, Middelburg JJ, Herman PMJ, Heip CHR (1999) Linking diagenetic alteration of amino acids and bulk organic matter reactivity. Limnol Oceanogr 44:1809-1844

Davies PS (1984) The role of zooxanthellae in the nutritional energy requirements of Pocillopora eydouxi. Coral Reefs 2:181-186

Duarte CM, Cebrian J (1996) The fate of marine autotrophic production. Limnol Oceanogr 41:1758-1766

Ducklow HW, Mitchell R (1979) Composition of mucus released by coral reef coelenterates. Limnol Oceanogr 24: 706-714

Hedges JI, Oades JM (1997) Comparative organic geochemistries of soils and marine sediments. Org Geochem 27:319-361

Hoegh-Guldberg O (1999) Climate change, coral bleaching and the future of the world's coral reefs. Mar Freshw Res 50:839-866

Huettel M, Gust G (1992) Solute release mechanisms from confined sediment cores in stirred benthic chambers and flume flows. Mar Ecol Prog Ser 82:187-197

Huettel M, Rusch A (2000) Transport and degradation of phytoplankton in permeable sediment. Limnol Oceanogr 45:534-549

Klute A, Dirksen C (1986) Hydraulic conductivity and diffusivity: laboratory methods. In: Klute A (ed) Methods of soil analysis. Part 1. Physical and mineralogical methods, 2nd edn. American Society of Agronomy, Madison, WI

Krupp DA (1981) The composition of the mucus from the mushroom coral Fungia scutaria. Proc 4th Int Coral Reef Symp 2:69-74

Llobet-Brossa E, Rabus R, Bottcher ME, Konneke M and 6 others (2002) Community structure and activity of sulfatereducing bacteria in an intertidal surface sediment: a multi-method approach. Aquat Microb Ecol 29:211-226

Marinelli RL, Jahnke RA, Craven DB, Nelson JR, Eckman JE (1998) Sediment nutrient dynamics on the South Atlantic Bight continental shelf. Limnol Oceanogr 43: 1305-1320

Markell DA, Trench RK, Iglesiasprieto R (1992) Macromolecules associated with the cell walls of symbiotic dinoflagellates. Symbiosis 12:19-31

Meikle P, Richards G, Yellowlees D (1988) Structural investigations on the mucus from 6 species of coral. Mar Biol 99: 187-193

Muscatine L, Porter JW (1977) Reef corals—mutualistic symbioses adapted to nutrient-poor environments. BioScience 27:454-460

Pareek S, Azuma J, Shimizu Y, Matsui S (2000) Hydrolysis of newspaper polysaccharides under sulfate reducing and methane producing conditions. Biodegradation 11: 229-237

Pascal H, Vacelet E (1981) Bacterial utilization of mucus on

Editorial responsibility: Otto Kinne (Editor-in-Chief), Oldendorf/Luhe, Germany the coral reef of Aqaba (Red Sea). Proc 4th Int Coral Reef Symp 1:669-677

Rasheed M, Badran M, Huettel M (2003a) Influence of sediment permeability and mineral composition on organic matter decomposition in three sediments from the Gulf of Aqaba, Red Sea. Estuar Coast Shelf Sci 57:369-384

Rasheed M, Badran M, Huettel M (2003b) Particulate matter filtration and seasonal nutrient dynamics in permeable carbonate and silicate sands of the Gulf of Aqaba, Red Sea. Coral Reefs 22:167-177

Rasheed M, Wild C, Franke U, Huettel M (2004) Benthic photosynthesis and oxygen consumption in permeable carbonate sediments at Heron Island, Great Barrier Reef, Australia. Estuar Coast Shelf Sci 59:139-150

Richter C, Wunsch M, Rasheed M, Kotter I, Badran MI (2001) Endoscopic exploration of Red Sea coral reefs reveals dense populations of cavity-dwelling sponges. Nature 413:726-730

Rusch A, Huettel M, Reimers CE, Taghon GL, Fuller CM (2003) Activity and distribution of bacterial populations in Middle Atlantic Bight shelf sands. FEMS Microbiol Ecol 44:89-100

Rusch A, Huettel M, Wild C, Reimers CE (in press) Benthic oxygen consumption and organic matter turnover in organic-poor, permeable shelf sands. Aquat Geochemistry

Schroeder JH, Purser BH (1986) Reef diagenesis. Springer, Berlin

Sedano FJ, Rodriguez JL, Ruiz C, Garciamartin LO, Sanchez JL (1995) Biochemical composition and fertilization in the eggs of Mytilus galloprovincialis (Lamarck). J Exp Mar Biol Ecol 192:75-85

Seiki T, Izawa H, Date E (1989) Benthic nutrient remineralization and oxygen-consumption in the coastal area of Hiroshima Bay. Water Res 23:219-228

Seiki T, Izawa H, Date E, Sunahara H (1994) Sediment oxygen-demand in Hiroshima Bay. Water Res 28:385-393

Wahbeh MI, Mahasneh AM (1989) Composition and bacterial utilization of mucus of corals from Aqaba (Red Sea), Jordan. Proc 6th Int Coral Reef Symp 2:53-57

Westrich JT, Berner RA (1984) The role of sedimentary organic matter in bacterial sulfate reduction: the $\mathrm{G}$ model tested. Limnol Oceanogr 29:236-249

Wild C, Huettel M, Klueter A, Kremb SG, Rasheed M, Jørgensen BB (2004a) Coral mucus functions as an energy carrier and particle trap in the reef ecosystem. Nature 428: $66-70$

Wild C, Rasheed M, Werner U, Franke U, Johnstone R, Huettel M (2004b) Degradation and mineralization of coral mucus in reef environments. Mar Ecol Prog Ser 267: 159-171

Wild C, Tollrian R, Huettel M (2004c) Rapid recycling of coral mass spawning products in permeable reef sediments. Mar Ecol Prog Ser 271:159-166

Wild C, Woyt H, Huettel M (2005) Influence of coral mucus on nutrient fluxes in carbonate sands. Mar Ecol Prog Ser 287: 87-98

Winkler LW (1888) The determination of dissolved oxygen in water. Ber Dtsch Chem Ges 21:2843-2857

Submitted: December 13, 2004; Accepted: March 13, 2005

Proofs received from author(s): July 25, 2005 